\section{Thieme journals fulfill your need for contemporary resources}

A diverse group of award-winning Editors complement our journals in a vast variety of specialties.
Read and submit

http://open.thieme.com

(https://adfarm1.adition.com/redi?

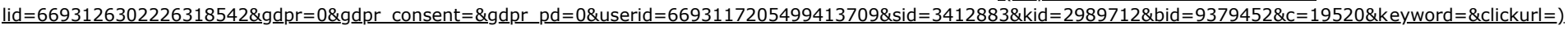
Planta Med 2014; 80 - P2B108 DOI: $10.1055 / \mathrm{s}-0034-1394985$

\title{
Evaluation of antioxidant activity of selected Brazilian plants extracts
}

C Pinho $\underline{1}, \underline{2}$, A Oliveira $\underline{1}, \underline{2}, \mathrm{~N}$ Paraíso $\underline{\underline{3}}$, A Carvalho $\underline{\underline{1}}$, C Lima $\underline{\underline{1}}$, A Dias $\underline{1}$

${ }^{\mathbf{1}}$ Centre for the Research and Technology of Agro-Environment and Biological Sciences (CITAB-UM), AgroBioPlant Group, Department of Biology, University of Minho, Portugal

${ }^{2}$ Núcleo de Investigação e Informação em Farmácia (NIF), Centro de Investigação em Saúde e Ambiente (CISA), Escola Superior de Tecnologia de Saúde do Porto

- Instituto Politécnico do Porto (ESTSP-IPP), Vila Nova de Gaia, Portugal

${ }^{3}$ Aromas Biotecnologia \& Agrobusiness, Salvador, Bahia, Brazil

Congress Abstract

Numerous diseases are induced by free radicals and it has long been recognized that naturally occurring substances in higher plants have antioxidant activity. This study aims to evaluate the antioxidant and protective effect of crude ethanolic extracts of plants from Bahia (Brazil), namely Poiretia bahiana (Pb), Acritopappus confertus (Ac), Cuphea carthagenensis (Cc) and Polygala ignatii (Pol). Antiradicalar activity of the extracts was measured using DPPH assay. Pb, Cc and Pol extracts proved to have radical scavenging activity. Ac showed the highest activity (EC50 $=30 \mu \mathrm{g} / \mathrm{ml}$ ). Additionally, human hepatocytes cells (HepG2) were submitted to oxidative stress induced by $\mathrm{t}-\mathrm{BOOH}$, in the presence of plants extracts in several experimental situations. In pre-incubation treatments, cells were incubated with extracts for $4 \mathrm{~h}$, followed by treatment with t-BOOH for $3 \mathrm{~h}$. For co-incubation treatments, cells were co-incubated with extracts and t-BOOH for $4 \mathrm{~h}$. Antioxidant status of HepG2 was assessed by measuring glutathione (GSH) levels. Pre-incubation with Ac and Pol extracts at $25 \mu \mathrm{g} / \mathrm{ml}$ presented the best results $(82.7 \%$ and $79.3 \%$ of cell viability, respectively) indicating that protective potential against cell death is probably achieved by induction of antioxidant defenses. Incubating HepG2 cells with Pol and Cc extracts resulted in induction of intracellular antioxidant GSH in a concentration-dependent manner. Pol concentration of 25 $\mu \mathrm{g} / \mathrm{ml}$ showing percentages higher than control (125\%) evidencing that extracts may have protective role against oxidative damage in liver tissue. Extracts co-incubated with $\mathrm{t}-\mathrm{BOOH}$ prevented cell death in all concentrations tested, indicating that the extracts possess direct antioxidant effects against $\mathrm{t}-\mathrm{BOOH}$ toxicity, eventually by their antiradical scavenging activity.

Acknowledgements: This work was supported by Fundação para a Ciência e Tecnologia (FCT), projects PTDC/AGRALI/105169/2008 and PEst-OE/AGR/UI4033/2014.

Keywords: Poiretia bahiana, Acritopappus confertus, Cuphea carthagenensis, Polygala ignatii, antioxidant activity 